\title{
Study on land use and carbon and economic growth in Nanjing
}

\author{
Chu Su ${ }^{*}$ Kuanqi $\mathrm{Du}$
}

School of Economics and Management, Nanjing University of Science and Technology, China

*Corresponding author: Chu Su, Postgraduate, 1455053725@qq.com

\begin{abstract}
In this paper, we study on the relationship between economic growth and land use and carbon emission in Nanjing from 2005 to 2014 shows that the economic growth and the carbon use of land use in Nanjing are not completely decoupled, that is, the change of land use carbon emissions with economic growth Showing an upward trend. Research proposals: Therefore, under the new normal situation of economic and social development, explore the use of low-carbon recycling economy-oriented land resource utilization and management model for the promotion of ecological civilization in Nanjing to provide new development ideas.
\end{abstract}

Key words: land use carbon emissions; low carbon green economy; Nanjing

\section{Research methods and data sources}

\subsection{Calculation of land use carbon emissions}

Land use of carbon emissions can be divided into two types, one is due to different types of land use caused by direct carbon emissions, and second, carrying human activities caused by indirect carbon emissions. The land use carbon emissions in this paper refer to direct carbon emissions, which are derived from cultivated land, other agricultural land, woodland, garden land, pasture land, construction land, water area and unused land. The land use carbon emission coefficient is affected by soil type way, farming habits and other aspects of the impact, with greater uncertainty. For the need for quantitative research, the following formula is introduced. Estimation of carbon emissions in cultivated land, woodland, garden, pasture, water and unused land :

$$
W=\sum S_{i} Q_{i}
$$

In Eqs.(1), $W$ is the total amount of carbon emissions of six types of cultivated land, forest land, garden land, pasture land, water area and unused land; $S_{i}$ is the area of the i land type; $Q_{i}$ is the carbon of the ith land Emission coefficient, according to the relevant literature, the carbon emission coefficient of cultivated land is $0.40 \mathrm{tc} / \mathrm{hm}^{2}$, and the carbon emission coefficients of garden land, forest land, grassland, water area and unused land are -0.39 
$\mathrm{tc} / \mathrm{hm}^{2},-0.64 \mathrm{tc} / \mathrm{hm}^{2},-0.02 \mathrm{tc} / \mathrm{hm}^{2},-0.25 \mathrm{th} / \mathrm{m}^{2},-0.005 \mathrm{tc} / \mathrm{hm}^{2}$. The main sources of carbon emissions from other agricultural land are livestock and poultry activities, agricultural production management activities. Such as the release of carbon. Other agricultural land carbon emissions calculation Eqs.(2):

$$
F=\sum \lambda_{k} Q_{k}+L \delta
$$

In Eqs.(2), $F$ is the total amount of carbon emissions from other agricultural land; $Q_{k}$ is the k-number of livestock; $\lambda_{k}$ is the emission coefficient of $k$-type livestock and livestock; $L$ is the other agricultural land area; $\delta$ is the other agricultural land management coefficient. According to the related literature, the carbon emission coefficients of cattle, sheep, pig and poultry were $0.79 t / a, 0.07 t / a, 0.08 t / a$, and $0.004 t / a$, respectively, and the other agricultural land management coefficient was 0.95t/a.

Will be involved in the production and life of energy consumption converted to standard coal, and then according to the energy carbon emission factor (derived from the IPCC carbon emissions guidelines) to be measured, you can get the total carbon emissions of construction land. According to the social and economic development of Nanjing, the selection of 10 major energy sources related to production and living in Nanjing was calculated. Calculation formula for carbon emissions of construction land:

$$
C=\sum P_{j}=\sum E_{j} R_{j}
$$

Table 1 -Standard conversion coefficient and carbon emission coefficient

\begin{tabular}{|l|l|l|}
\hline Energy & Conversion coefficient of standard coal & Carbon emission coefficient \\
\hline Coke oven gas $(\mathrm{m} 3)$ & $0.5714 \mathrm{kgec} / \mathrm{m} 3$ & $0.3548 \mathrm{~kg} \odot / \mathrm{kgec}$ \\
\hline Other petroleum products $(\mathrm{kg})$ & $1.228 \mathrm{kgec} / \mathrm{t}$ & $0.5857 \mathrm{~kg} \odot / \mathrm{kgec}$ \\
\hline Liquefied petroleum gas $(\mathrm{kg})$ & $1.7143 \mathrm{kgec} / \mathrm{t}$ & $0.5042 \mathrm{~kg} \odot / \mathrm{kgec}$ \\
\hline Fuel oil $(\mathrm{kg})$ & $1.4286 \mathrm{kgec} / \mathrm{t}$ & $0.6185 \mathrm{~kg} \odot / \mathrm{kgec}$ \\
\hline Washing coal $(\mathrm{kg})$ & $0.9 \mathrm{kgec} / \mathrm{t}$ & $0.7559 \mathrm{~kg} \odot / \mathrm{kgec}$ \\
\hline Gasoline $(\mathrm{kg})$ & $1.4714 \mathrm{kgec} / \mathrm{t}$ & $0.5538 \mathrm{~kg} \odot / \mathrm{kgec}$ \\
\hline Diesel $(\mathrm{kg})$ & $1.4571 \mathrm{kgec} / \mathrm{t}$ & $0.5921 \mathrm{~kg} \odot / \mathrm{kgec}$ \\
\hline Kerosene $(\mathrm{kg})$ & $1.4714 \mathrm{kgec} / \mathrm{t}$ & $0.5714 \mathrm{~kg} \odot / \mathrm{kgec}$ \\
\hline Raw coal $(\mathrm{kg})$ & $0.7143 \mathrm{kgec} / \mathrm{t}$ & $0.7559 \mathrm{~kg} \odot / \mathrm{kgec}$ \\
\hline Coke $(\mathrm{kg})$ & $0.9714 \mathrm{kgec} / \mathrm{t}$ & $0.855 \mathrm{~kg} \odot / \mathrm{kgec}$ \\
\hline
\end{tabular}

In Eqs.(3), $C$ is the total carbon emission of the construction land; $P_{j}$ is the total carbon emission of the $j$ energy; $R_{j}$ is the carbon emission coefficient of the $j$ energy; $E_{j}$ is the 
amount of coal in the jth energy $\left(E_{j}=W_{j} V\right.$, where: $W_{j}$ is the consumption of the $j$ energy and $V$ is the conversion factor of the coal) (Table 1 ).

\section{2 decoupling theory and TAPIO model selection}

The original meaning of "decoupling" means that two or more objects that have a corresponding relationship cease to be interrelated. Decoupling relationship can be divided according to the degree of relative decoupling and absolute decoupling. In this paper, the relative decoupling refers to the change in land use carbon emissions with economic growth and an upward trend. Absolute decoupling refers to the change in land use carbon emissions with economic growth and a downward trend.

This paper uses the decoupling theory to analyze the relationship between economic growth and land use carbon emissions in Nanjing. Since the nature of the TAPIO model is elasticity, it has a comparative advantage in stability and accuracy, and is not disturbed by the statistical dimension. Therefore, the TAPIO model is used to calculate the model as shown in Eqs.(4).

$$
D I=\frac{\left(E P_{t 1}-E P_{t 0}\right) / E P_{t 0}}{\left(D P_{t 1}-D P_{t 0}\right) / D P_{t 0}}
$$

In Eqs.(4), DI is the decoupling index; the land use carbon emissions as EP (environmental pressure variable); GDP as DP (economic drive variable); $t_{0}, t$ are the beginning and end of the time period. The TAPIO decoupling model is essentially elastic and is divided into eight decoupling states according to the magnitude of the elasticity that showing in Table 2.

Table 2- TAPIO decoupling state division

\begin{tabular}{|l|l|l|l|l|l|}
\hline \multirow{2}{*}{} & $\begin{array}{l}\text { Serial } \\
\text { number }\end{array}$ & status & $\begin{array}{l}\text { Environmenta } \\
\text { l stress }\end{array}$ & $\begin{array}{l}\text { Economic } \\
\text { drive }\end{array}$ & $\begin{array}{l}\text { Decoupling } \\
\text { index }\end{array}$ \\
\hline \multirow{2}{*}{ Decouplin } & $(1)$ & Decay decoupling & $<0$ & $<0$ & DI $>1.2$ \\
\cline { 2 - 6 } & $(2)$ & Strong decoupling & $<0$ & $>0$ & DI $<0$ \\
\cline { 2 - 6 } & $(3)$ & Weak decoupling & $>0$ & $>0$ & $0<$ DI $<0.8$ \\
\hline \multirow{2}{*}{ Link } & $(4)$ & Growth link & $>0$ & $>0$ & $0.8<\mathrm{DI}<1.2$ \\
\cline { 2 - 6 } decoupling & $(5)$ & Recession link & $<0$ & $<0$ & $0.8<\mathrm{DI}<1.2$ \\
\cline { 2 - 6 } & $(6)$ & Expansion negative decoupling & $>0$ & $>0$ & $\mathrm{DI}>1.2$ \\
\cline { 2 - 6 } & $(8)$ & Strong negative decoupling & $>0$ & $<0$ & $\mathrm{DI}<0$ \\
\hline
\end{tabular}

\subsection{Data sources}

The data used in this paper are from "Nanjing Statistical Yearbook (2006 2015)" Nanjing Economic Statistical Yearbook (2006 2015) ", and the land change survey data from 2005 to 2014 comes from Nanjing Land and Resources Bureau. 
Table 3- Nanjing City (2005 2014) economic growth and land use carbon emissions decoupling relationship

\begin{tabular}{|c|c|c|c|c|c|c|}
\hline Time & $\begin{array}{l}\text { Changes in land } \\
\text { use carbon } \\
\text { emissions (t) }\end{array}$ & $\begin{array}{l}\text { Change in } \\
\text { GDP (billion } \\
\text { yuan) }\end{array}$ & $\begin{array}{l}\text { Land use change } \\
\text { rate of carbon } \\
\text { emissions }\end{array}$ & $\begin{array}{l}\text { GDP rate } \\
\text { of change }\end{array}$ & $\begin{array}{l}\text { DI } \\
\text { decoupling } \\
\text { index }\end{array}$ & $\begin{array}{l}\text { Decoupling } \\
\text { status }\end{array}$ \\
\hline $\begin{array}{l}2005 \sim ~ \\
2006\end{array}$ & 408667 & 303.33 & 0.04 & 0.13 & 0.34 & $\begin{array}{l}\text { Weak } \\
\text { decoupling }\end{array}$ \\
\hline $\begin{array}{l}2006 \sim \\
2007\end{array}$ & -179804 & 368.41 & -0.02 & 0.14 & -0.13 & $\begin{array}{l}\text { Strong } \\
\text { decoupling }\end{array}$ \\
\hline $\begin{array}{l}2007 \sim \\
2008\end{array}$ & -637781 & 279.36 & -0.07 & 0.09 & -0.73 & $\begin{array}{l}\text { Strong } \\
\text { decoupling }\end{array}$ \\
\hline $\begin{array}{l}2008 \sim \\
2009\end{array}$ & -80795 & 402.26 & -0.01 & 0.12 & -0.08 & $\begin{array}{l}\text { Strong } \\
\text { decoupling }\end{array}$ \\
\hline $\begin{array}{l}2009 \sim \\
2010\end{array}$ & 4051365 & 502.11 & 0.47 & 0.14 & 3.43 & $\begin{array}{l}\text { Expansion } \\
\text { negative } \\
\text { decoupling }\end{array}$ \\
\hline $\begin{array}{l}2010 \sim \\
2011\end{array}$ & 2994739 & 678.82 & 0.24 & 0.16 & 1.45 & $\begin{array}{l}\text { Expansion } \\
\text { negative } \\
\text { decoupling }\end{array}$ \\
\hline $\begin{array}{l}2011 \sim \\
2012\end{array}$ & 351464 & 682.46 & 0.02 & 0.14 & 0.16 & $\begin{array}{l}\text { Weak } \\
\text { decoupling }\end{array}$ \\
\hline $\begin{array}{l}2012 \sim \\
2013\end{array}$ & -314899 & 459.79 & -0.02 & 0.08 & -0.24 & $\begin{array}{l}\text { Strong } \\
\text { decoupling }\end{array}$ \\
\hline $\begin{array}{l}2013 \sim \\
2014\end{array}$ & -366404 & 437.21 & -0.02 & 0.07 & -0.32 & $\begin{array}{l}\text { Strong } \\
\text { decoupling }\end{array}$ \\
\hline
\end{tabular}

\section{Results and analysis}

The results are shown in Table 3 that the decoupling relationship between economic growth and land use carbon emissions in Nanjing shows the following three states:

(1) Weak decoupling state: 2005 2006, 2011 2012 growth and land use of carbon emissions showed a weak decoupling state, indicating that changes in land use of carbon emissions with economic growth and an upward trend, but the rate of change in carbon emissions To be less than the rate of change in economic growth. This state is the ideal state for the development of low carbon recycling economy in the process of urban expansion.

(2) Strong decoupling state: 2006 2007, 2007 2008, 2008 2009, 2012 2013 economy 
and 2013 2014 economic growth and land use

Carbon emissions show a strong decoupling state, indicating that the amount of land use of carbon emissions with the economic growth and a downward trend. This state is the best state for the development of low carbon recycling economy in the process of urban expansion.

(3) Expansion negative decoupling state: 2009 2010 and $2010 \sim 2011$

Year economic growth and land use carbon emissions show negative expansion and decoupling state, indicating that the change in land use carbon emissions with the economic growth and an upward trend, and carbon change rate of change is greater than the rate of economic growth rate of change. This state is the most undesirable state for the development of low-carbon recycling economy in the process of urban expansion.

Further analysis shows that the decoupling relationship between economic growth and land use carbon emissions fluctuates between strong decoupling and weak decoupling, and mainly shows a strong decoupling state, that is, the change in land use carbon emissions decreases with economic growth. But the overall decoupling state is unstable, indicating that the land use of carbon emissions and economic growth in Nanjing did not achieve a complete decoupling.

In order to further verify the relationship between economic growth and land use carbon emissions in Nanjing, the economic growth and land use carbon emissions in Nanjing from 2005 to 2014 were compared and analyzed separately (Fig. 1). The dimensionless formula is:

$$
X_{i}=\left(X_{i}-X_{\min }\right) /\left(X_{\max }-X_{\min }\right)
$$

Where $X i$ denotes the standard value of the indicator, $X i$ denotes the original value of the indicator, $X_{\min }$ denotes the minimum value of the index, and $X_{\max }$ denotes the maximum value of the index.

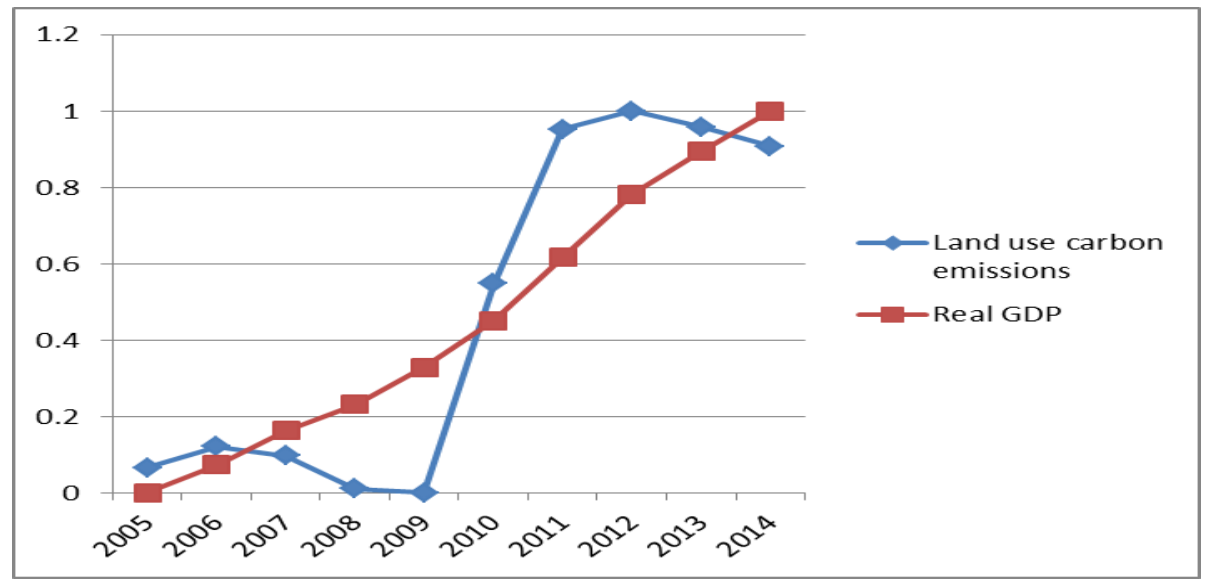

Fig.1- Nanjing economic growth and land use carbon emissions relationship

As can be seen from Figure 1, the land use carbon emissions show an upward trend with the growth of the economy. However, the carbon emissions of land use declined first, then increased, and then declined, showing a very unstable state. It further illustrates that there is no decoupling between economic growth and land use carbon emissions in Nanjing. In the 
process of urban expansion, Nanjing needs to change its mode of economic development, adjust its industrial structure and develop low-carbon circular economy.

The amount of carbon emission from 2009 to 2010 in a major turning point, the reasons are: (1) Affected by the financial crisis in 2008, China has introduced a variety of policies to stimulate the economy, which makes the economic operation since 2008 in a rapid expansion of state. (2) The lagging effect of government policy. (3) The lack of attention to the low-carbon industry in the process of economic expansion leads to a negative decoupling between land use carbon emissions and economic growth.

\section{Suggestions on utilization and management of land resources under the guidance of low carbon cycle economy}

\subsection{Establish a land use planning system under the guidance of low carbon recycling economy}

According to the situation of carrying capacity of resources and environment in Nanjing, local governments should rationally determine the scale of urban development. And according to the requirement of low carbon development, policy makers should adjust and optimize the spatial structure, and scientifically layout the production space, living space and ecological land. Local governments should develop a green economy, explore a low carbon recycling economy oriented land use planning system, and promote the rapid development of low-carbon industries.

\subsection{Innovative land use management model under the guidance of low carbon cycle economy}

Policy makers and research scholars should explore the ecological compensation mechanism of land use in Nanjing, while taking advantage of the advantages of resources, adhere to the green development, innovation for low-carbon recycling economy development of land use management model. The government should develop a negative list of land use carbon emissions, through strict restrictions on high energy consumption industry land use approval to form a mechanism to promote the optimization and upgrading of industrial structure. On the other hand, policy makers should increase the policy support and financial security of Nanjing main agricultural products and key ecological functional areas, strengthen incentive compensation measures, and strengthen the management of land use planning binding indicators. The government should take the land supply approval management as the starting point to promote the development of low carbon industry, and formulate the corresponding land use policy to support the strategic development of new industries.

\subsection{Improve land use efficiency under low carbon green economy}

The government should combine the conservation, intensive land use and the development of low-carbon green economy, gradually reduce the proportion of industrial land, and introduce 
the concept of low carbon recycling economy in the land saving and intensive use. Policy makers should provide new materials enterprises, new energy research enterprises, and recycling enterprises of "three wastes" resources to form an industrial structure conducive to conservation of resources and ecological protection.

\section{References}

1. Qu Futian, Lu Na, Feng Shuei. Effects of Land Use Change on Carbon Emissions [J]. China Population, Resources and Environment, 21 (2011):76 -83.

2. Peng Jiawen, Huang Xianjin, Zhong Taiyang, et al. Decoupling of China's Economic Growth and Energy Carbon Emissions [J]. Resources Science, 33 (2011)626-633.

3. Cheng Ziteng, Yan Jinming, Gao Feng. Land use carbon emissions and economic growth - Taking Liuzhou City as an example [J]. Eco-economy, 32 (2016)87-89.

4. Feng Zhijun, Zhou Rong. Low-carbon economy: the fundamental way to achieve green development in China [J]. China Population, Resources and Environment, 20 (2010)1-7. 